\title{
Lipids and trophic linkages in harp seal (Phoca groenlandica) from the eastern Barents Sea
}

\author{
Stig Falk-Petersen, Tore Haug, Kjell T. Nilssen, \\ Anette Wold \& Trine M. Dahl
}

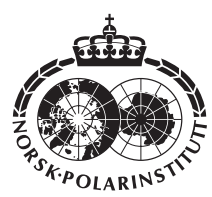

Fatty acid profiles and lipid biomarkers from 20 harp seals were used to investigate the foraging ecology of harp seals and the transfer of energy through the Franz Josef Land-Novaya Zemlya food chain. High levels of the Calanus fatty acid trophic markers (FATMs) 20:1(n-9) (mean 14.6\%) and 22:1(n-11) (mean 6.5\%), together with the typical dinoflagellate FATMs 22:6(n-3) (mean 6.5\%) and C18PUFA (mean 5.5\%), were found in blubber samples. Based on the analyses of the fatty acid profiles separated by principal component analysis, we confirmed the importance of polar cod (Boreogadus saida) and the pelagic amphipod Themisto libellula in the diet of harp seal. The high levels of 22:6(n-3), C18PUFA and C20 and C22 FATMs show that the harp seal lipids mainly originate from dinoflagellates consumed by Calanus copepods.

S. Falk-Petersen, A. Wold \& T. M. Dahl, Norwegian Polar Institute, Polar Environmental Centre, NO-9296 Tromsø, Norway, stig@npolar.no; T. Haug \& K. T. Nilssen, Institute of Marine Research, Box 6404, NO9226 Tromsø, Norway.

Three populations of harp seals (Phoca groenlandica) inhabit the North Atlantic. Whelping occurs east of Newfoundland and in the Gulf of St. Lawrence (the north-west Atlantic stock), off the east coast of Greenland (the Greenland Sea stock) and in the White Sea (the Barents Sea/White Sea stock) (Sergeant 1991). One of the most numerous mammalian species in the North Atlantic, the harp seal is an important predator both in the north-west Atlantic (Beck et al. 1993; Lawson \& Stenson 1997; Hammill \& Stenson 2000) and the north-east Atlantic (Nilssen, Haug, Potelov, Stasenkov et al. 1995; Nilssen, Haug, Potelov \& Timoshenko 1995; Nilssen et al. 2000; Lindstrøm et al. 1998; Haug et al. 2000). During autumn and early winter (July-December) the harp seal populations of the Greenland Sea and the Barents Sea/ White Sea overlap in the northern and north-eastern Barents Sea (Sivertsen 1941; Haug et al. 1994; Folkow et al. 2004). This is a period with intensive feeding and blubber deposition; the seals are fat and in good body condition in September-
October (Nilssen, Haug, Potelov \& Timoshenko 1995; Nilssen et al. 1997). In early winter (December) the seals migrate towards their breeding and moulting areas in the White Sea/south-eastern Barents Sea and Greenland Sea (Haug et al. 1994; Folkow et al. 2004).

Seal diet has been studied through analyses of gastrointestinal tract contents (Lindstrøm et al. 1998; Wathne et al. 2000) and prey remains in faecal samples (Fea \& Harcourt 1997; Lea et al. 2002). Although such analyses provide important qualitative and quantitative information, they are biased. For example, prey species lacking hard parts or whose hard parts are easily digested may be underestimated, whereas prey with hard parts such as squid beaks may be overestimated (Pierce \& Boyle 1991; Bowen 2000; Arim \& Naya 2003). Another shortcoming is that only the last meal, often consumed near haul-out and breeding localities, can be studied. Prey from other parts of the species' foraging range may be missed.

Lipids have been used as trophic markers to 
study predator-prey relations (Falk-Petersen et al. 1990, Falk-Petersen et al. 2002). The origins of fatty acid trophic markers (FATMs) can be identified to specific taxa. Transferred from one trophic level to the next, they provide insight into ecosystem dynamics by indicating pathways of energy flow (Dalsgaard et al. 2003). Commonly known FATMs are: 20:5(n-3) for diatoms; 22:6(n-3) and C18PUFA (polyunsaturated fatty acids) for dinoflagellates-Phaeocystis phouchetii; and C20 and C22 monounsaturated fatty acids for Calanus copepods (Table 1).

Fatty acid (FA) profiles in predators show an integration of prey over periods from weeks to months (Bowen 2000; Arim \& Naya 2003), providing information beyond what can be obtained from stomach content alone. Some FAs are biosynthesized de novo by animals, but essential FAs with a double bond at n-3 and n- 6 are never synthesized by mammals (Cook 1985). During periods of fattening, FAs absorbed from the diet go directly to fat deposits used for energy storage or insulation (Iverson 1995). Blubber from seals sampled after a period of intensive feeding with subsequent fat deposition will in principle reflect the FA profile of their important prey species. Multivariate statistical methods have been introduced in FA signature analysis (Grahl-Nielsen \& Mjaavatten 1991; Iverson 1993). Such methods allow comparison not just of single FAs but of entire FA profiles in animal tissues, making it possible to detect relationships and patterns within complex data (Birks 1987). Analyses of FA profiles have been used in a number of dietary studies of mammals (Iverson et al. 1997; Brown et al. 1999; Dahl et al. 2003; Walton \& Pomeroy 2003).

The objectives of this study were: to describe FAs in the blubber of harp seal during the pre-

Table 1. The principle Fatty Acid Trophic Markers (PUFA is polyunsaturated fatty acids).

\begin{tabular}{ll}
\hline Bio-indicators & Taxa \\
\hline 22:6(n-3) and C18PUFA & Dinoflagellates \\
18:4(n-3), 18:5(n-3), 18:2(n-6) & Phaeocystis pouchetii \\
20:5(n-3) and C16PUFA & Diatoms \\
16:4(n-1) & Melosira arctica \\
20:4(n-6) & Benthic littoral algae \\
20:1(n-9) and 22:1(n-11) & Calanus copepod \\
Phytol & Phytoplanktonic origin \\
C25PUFA & Sediment detritus \\
Branched fatty acids & Bacteria \\
\hline
\end{tabular}

breeding season in autumn; to study trophic linkages through FATM at this period; and to examine prey selection through FA profiles and compare these results with stomach/gut content analyses.

\section{Materials and methods}

\section{Sampling}

A Joint Norwegian-Russian Fisheries Commission agreement permitted up to 500 harp seals to be caught in the northern Barents Sea for scientific purposes in 1995. Twenty harp seals were shot on ice floes in a relatively restricted area south-east of Franz Josef Land between 21 and 25 October 1995 (Nilssen et al. 1997). Dorsal blubber cores, ca. $5 \times 5 \mathrm{~cm}$, were taken through the full depth of the blubber layer at the midline between the front flippers. The cores were immediately wrapped in aluminium foil, packed in plastic bags and frozen at $-20^{\circ} \mathrm{C}$ until analysed.

Prior to analysis, to assess the quality of lipid after the long period of storage, the levels of free fatty acids (FFAs) in the total lipid extracts were measured using high performance thin layer chromatography (Falk-Petersen et al. 2002). FFA levels were ca. $3 \%$, indicating that the blubber lipid had not markedly degraded and the quality of the samples was adequate for our analyses.

\section{Size and age}

Seals were weighed to the nearest $\mathrm{kg}$ (W). Lengths (L) were measured from the tip of the snout to the tip of the tail, and the dorsal blubber (d) was measured in $\mathrm{mm}$ in a knife cut along the midline between the front flippers (Nilssen et al. 1997). The condition index (C) (Ryg et al. $1990)$ is expressed as $\mathrm{C}=\sqrt{ }(\mathrm{L} / \mathrm{W}) * \mathrm{~d}$ (Table 2). There are other methods for calculating condition indices (Tierney et al. 2001); we chose this method because it has been validated for harp seals (Nilssen et al. 1997). The blubber thickness is taken as an indicator of the general condition of the animals and reflects the life history of the animal during the last few months. One canine tooth was extracted after boiling the jaw. From each tooth, a 10-12 $\pi \mathrm{m}$ transverse section was mounted on a glass slide. Sections were examined under transmitted light and ages estimated from counts of growth layers in the dentine, by one experienced reader (Bowen et al. 1983). 
Fatty acid analysis of harp seals

Near-muscle blubber $(10 \mathrm{~mm}$ thick, $2 \mathrm{~mm}$ diameter) was taken from the full dorsal core for FA analysis. The inner blubber layer was used because this layer is metabolically active and the FA profile will reflect the recent diet, as shown in studies of minke whales (Balaenoptera acutorostrata) (Olsen \& Grahl-Nielsen 2003) and elephant seals (Mirounga leonina) (Best et al. 2003).

The samples were thawed, transferred to test tubes and $5 \mathrm{ml} \mathrm{2:1} \mathrm{chloroform/methanol} \mathrm{with}$ butylated hydroxytoluene (BHT) was added. Total lipid was extracted using the method of Folch et al. (1957). Lipid class composition was measured by quantitative thin-layer chromatography (TLC) densitometry (Olsen \& Henderson 1989). Triacylglycerols (TAG) were separated on TLC silica gel plates using hexane:diethyl ether:acetic acid $(90: 10: 1$, by volume). The samples were supplemented with a known amount of the FA 21:0, as an internal standard, and transmethylated in methanol containing $1 \%$ sulphuric acid with toluene for 16 hours at $50^{\circ} \mathrm{C}$. Fatty acid methyl esters (FAMEs) were purified by TLC using hexane:diethyl ether:acetic acid (85:15:1, by volume) as the developing solvent. They were recovered from

Table 2. Age, sample number, sex, length, weight, dorsal blubber thickness and condition index $(\mathrm{C}=\sqrt{ }(\mathrm{L} / \mathrm{W}) * \mathrm{~d})$ of the 20 harps seals caught in the Barents Sea, October 1995.

\begin{tabular}{crccccc}
\hline Age & No. & Sex & $\begin{array}{c}\text { Length } \\
(\mathrm{L})(\mathrm{cm})\end{array}$ & $\begin{array}{c}\text { Weight } \\
(\mathrm{W})(\mathrm{kg})\end{array}$ & $\begin{array}{c}\text { Dorsal } \\
\text { blubber }(\mathrm{d})\end{array}$ & $\mathrm{C}$ \\
\hline 0 & 12 & M & 106 & 41 & 43 & 69 \\
0 & 14 & M & 109 & 38 & 31 & 53 \\
1 & 3 & M & 122 & 51 & 33 & 51 \\
1 & 13 & M & 118 & 48 & 32 & 50 \\
1 & 30 & M & 126 & 51 & 45 & 71 \\
2 & 6 & F & 116 & 43 & 31 & 51 \\
2 & 28 & F & 110 & 68 & 56 & 71 \\
3 & 26 & F & 150 & 81 & 54 & 73 \\
9 & 15 & F & 150 & 71 & 29 & 42 \\
9 & 18 & F & 162 & 81 & 36 & 51 \\
10 & 29 & M & 175 & 154 & 75 & 80 \\
12 & 20 & M & 162 & 109 & 50 & 61 \\
12 & 24 & M & 167 & 140 & 62 & 68 \\
13 & 23 & M & 151 & 104 & 49 & 59 \\
16 & 21 & F & 171 & 154 & 75 & 79 \\
17 & 19 & M & 180 & 167 & 68 & 71 \\
17 & 42 & F & 167 & 106 & 39 & 49 \\
21 & 17 & M & 177 & 148 & 68 & 74 \\
23 & 25 & F & 171 & 159 & 80 & 83 \\
24 & 22 & M & 173 & 153 & 69 & 73 \\
\hline
\end{tabular}

the absorbent by elution with BHT. FAMEs were identified and quantified by gas chromatography. This was done by comparison with well characterized marine fish oils, as described by Dahl et al. (2000). Results are given as relative percentages of the different FAMEs.

\section{Fatty acid analysis of prey species}

Data on lipid composition of potential prey species were available for the euphausiid Thysanoessa inermis, polar cod (Boreogadus saida), the liparids Liparis fabricii and L. liparis collected in Kongsfjorden, Spitsbergen, in September 1999 (Falk-Petersen et al. 2000; Falk-Petersen unpubl. data) and the amphipod Themisto libellula collected north of Svalbard in September 1998 (FalkPetersen unpubl. data). The species included were, by mass, the most dominant species likely to be potential food for the harp seals in 1995 (Lindstrøm et al. 1998; Gjøseter 1998; Wathne et al. 2000). FA analyses of all prey species, except for polar cod, included whole individuals.

\section{Data processing}

In seals, ingested wax esters (WE) are hydrolysed to FFAs and free fatty alcohols which then are assimilated and subsequently converted to TAG or regenerated to WE (Falk-Petersen et al. 2002). To compare WE and TAG ingested by an animal to TAG and WE deposited, they need to be treated as one and the same. This is done by averaging (by molecular weights) given fatty alkyl and fatty acyl units of WE with the same chain lengths and numbers and positions of double bonds. The compositional data can then be related to neutral lipid in a predator consuming WE, irrespective of whether the predator converts its dietary WE to TAG or deposits them directly as WE. We use the term "moiety" for all processed data (FalkPetersen et al. 2002).

\section{Statistical analyses}

Moieties with low amounts $(<0.5 \%)$ in all samples were excluded because the precision of their determination is low. Remaining percentage values were log-transformed $(\log +1)$ to level out differences between FAs presented in large and small amounts. This method has been used previously for similar data (Dahl et al. 2000; Dahl et al. 2003, Olsen \& Grahl-Nielsen 2003). The log 
transformed values were subjected to principal component analysis (PCA) (Wold 1987), using the SIRIUS program package (Kvalheim \& Karstang 1987). Only components having eigenvalues $>1$ and that accounted for at least $5 \%$ of the total variance were considered significant and retained for evaluation (Hair 1998). First, PCA was used to compare individual seals based on blubber FAs. Second, PCA was used to examine relationships between seals and potential prey items based on their moiety compositions. To analyse the effect of prey species on the moiety compositions, the samples' principal component scores were used as response variables in an analysis of variance (ANOVA, type III sum of squares; Sokahl \& Rohlf 1995), followed by Tukey's honestly significant difference (HSD) test (Day \& Quinn 1989). The $\alpha$-level was $\leq 0.05$. The tests were performed in SAS 8.0 (SAS Institute Inc.). Individual samples (n) were included in all analyses, but for simplicity only mean values are presented. Again, only components with eigenvalues $>1$, accounting for $\geq 5 \%$ of the total variance, were retained for evaluation (Hair et al. 1998). Condition indices and Calanus FATM were compared in a simple regression analyses (SIRIUS; Kvalheim \& Karstang 1987) to investigate the importance of Calanus in the food chain leading to harp seals.

\section{Results}

\section{Size and age}

The sampled seals ranged in age from underyearlings to 24 years and weighed from 38 to nearly $160 \mathrm{~kg}$ (Table 2). The sample can be divided in three age categories: 8 young animals ( 0 - 3 years); 6 animals in the middle age group (9-13 years); and 6 older animals (16-24 years). The older individuals had high condition index (except females nos. 15, 18 and 42); among the young animals there was larger variation in the condition index.

\section{Fatty acid profiles}

Twenty-six FAs were found at levels $>0.5 \%$ of total in at least one individual (Table 3). These FAs constituted $94-99 \%$ of the total FAs detected. In harp seals the saturated FAs 14:0 and 16:0 occurred at mean levels of $7.6 \%$ and $9.5 \%$, respec- tively (Table 4$)$. There were also moderate levels of the monounsaturated 18:1(n-7) (3.2\%) and high levels of 18:1(n-9) (14.4\%). Large amounts of the copepod biomarker 20:1(n-9) were found (mean $14.6 \%$ ); values in seals nos. 18,26 and 29 were as high as $21-23 \%$. Moderate amounts of $22: 1(n-11)$ (mean $6.5 \%$ ) were also recorded. Of the phytoplankton FATMs, 22:6(n-3) was recorded at high levels (mean 9.6\%), followed by 16:1(n-7) (9\%), 20:5(n-3) (5.8\%), C18PUFA (5.5\%) and 22:5(n-3) $(3.8 \%)$.

PCA resulted in principal components (PCs) explaining $84 \%$ of the total variance ( $\mathrm{PC1}: 58 \%$, PC2: $15 \%$, PC3: $11 \%$ ). The separation of the different individuals along PC1 and PC2 is shown in Fig. 1a. Based on the loadings of FAs along PC1 (Fig. 1b), the main cause of separation of individuals was differences in levels of the Calanus FATM C20 and C22 monounsaturated FAs (high in nos. 24, 29, 18, 28 and 26, and low in nos. 15, $12,13,6,25$ and 42). The main cause of separation along PC2 was differences in levels of the diatom FATM 20:5(n-3) and 16:1(n-7) (high in no. 42 , low in no. 3). To a lesser extent, differences in levels of 18:3(n-3) and the dinoflagellate biomarker 22:6(n-3) (high in nos. 3 and 19, and low in nos. 29 and 26) caused separation along PC2.

\section{Fatty acids in potential prey}

The exploration of FA composition of harp seal and its potential prey by PCA (Fig. 2) resulted in the extraction of four significant PCs. In combination, these PCs explained $89 \%$ of the total variance (PC1: 49\%, PC2: 22\%, PC3: 12\%, PC4: $6 \%$ ). The samples' scores on all four PCs were explained by species variations (ANOVA $\mathrm{F}_{5,38}$ $>8.8, p<0.001$, adjusted $\mathrm{R}^{2}>0.5$ ). Krill (Thysanoessa inermis) and liparids clustered separately to the left side because of the low levels of 20:1(n9) and 22:1(n-11) and low level of 18:1(n-7). Harp seal scores on PC1 did not differ from polar cod and T. libellula, mainly due to the high level of 20:1(n-9) and 22:1(n-11) in all species. Harp seal differed from both prey species along PC2, mainly due to the exceptionally high level of $22: 5(n-3)$ and the dinoflagellate biomarker 22:6(n-3). There was no significant relationship between the condition index and levels of 20:1 and 22:1 moieties (Fig. 3). However, all animals with a condition index above 60 had high 20:1 and 22:1 levels. The exception - the under-yearling, no. 12 - had good condition and low 20:1 and 22:1 levels. 
Fig. 1. (a) Principal component plot of 20 harps seals based on TAG fatty acid composition in blubber. PC1 and $\mathrm{PC} 2$ explain $58.4 \%$ and $15.4 \%$ of the total variance, respectively. (b) Loading plot showing each of the 26 TAG fatty acids (from Table 1) and their contribution to the spread of seal samples along $\mathrm{PC} 1$ and $\mathrm{PC} 2$. The asterisk indicates both n-9 and n-11 isomers.
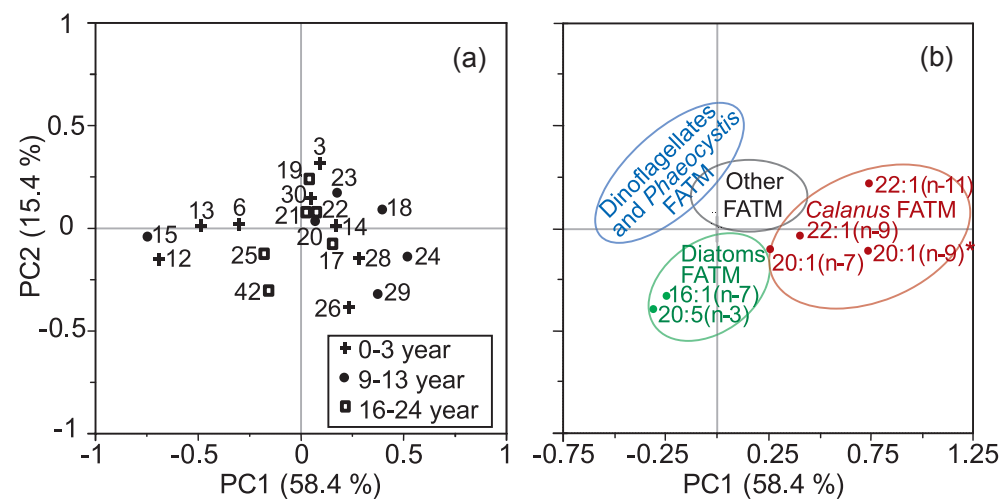

\section{Discussion}

The FA signatures showed a stronger relationship between harp seal and both polar cod and T. libelulla than to the other fish species (L. fabricii and L. liparis) and krill. Gastrointestinal tract contents from the same animals confirmed a diet dominated by the pelagic amphipod T. libellula and polar cod. In addition, a few fish species, including liparids and cottids, and shrimps were found in low numbers in a few gastrointestinal tracts (Lindstrøm et al. 1998). The harp seal diet in the northern Barents Sea in 1990-92 was dominated by amphipods in September and capelin (Mallotus villosus) and to a lesser extent polar cod in October (Nilssen, Haug, Potelov \& Timoshenko 1995). The lack of capelin in the harp seal diet in 1995 could be due to the collapse of the capelin stock in 1992/1993 (Barrett 2002). The eastern location of the October 1995 sampling area may also have been outside the usual range of the Barents Sea capelin (Gjøsæter 1998).

The use of FATMs in food chain studies is based on the observation that marine primary producers lay down FA patterns characteristic of different taxa that may be transferred through the food chain (Sargent \& Falk-Petersen 1981; Dalsgaard et al. 2003). The diatom-and-dinoflagellate- $P$. phouchetii FATM, together with specific markers produced by Calanus spp., can then be followed through the ecosystem via the herbivores to predators (Falk-Petersen et al. 1986; Falk-Petersen et al. 1990; Dahl et al 2003). Of the important phytoplankton in polar waters, the diatoms tend to be rich in 20:5(n-3) and 16:1(n7) but deficient in C18PUFA. The dinoflagellates- $P$. phouchetii tend to be rich in C18PUFA and 22:6(n-3), but deficient in 16:1(n-7). The high

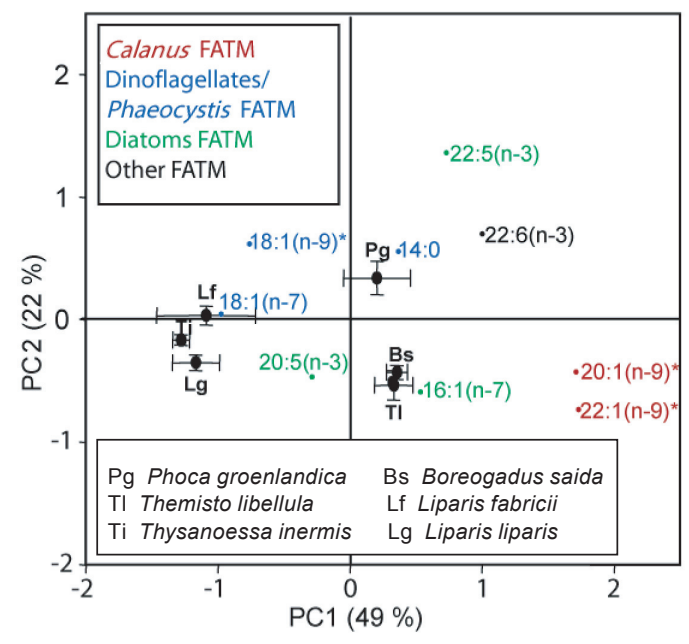

Fig. 2. Principal component plot of seal blubber samples and potential prey based on sample moiety compositions. Samples are presented by their mean score value \pm standard deviation on PC1 and PC2. Only moieties with high loadings on any of the significant extracted PCs are presented. The asterisk indicates both $\mathrm{n}-9$ and $\mathrm{n}-11$ isomers.

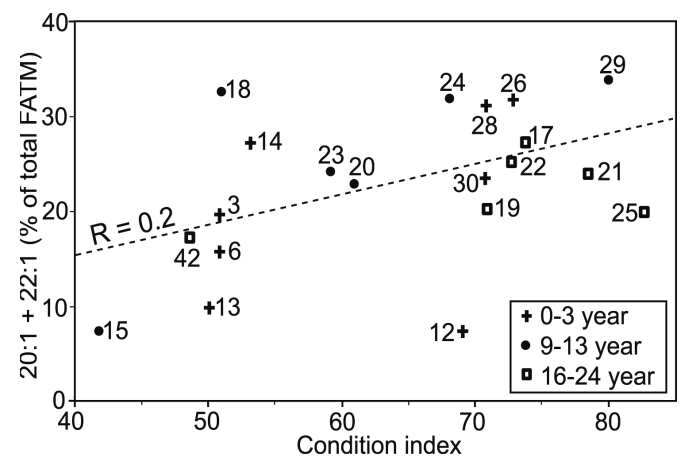

Fig. 3. Relation between condition index and the sum of all 20:1 and 22:1 moieties. Individuals are numbered as in Table 2. 
levels $(22 \%)$ of the dinoflagellate- $P$. phouchetii FATMs in harp seal blubber contrast with the FA composition of beluga whales (Delphinapterus leucas) and northern fulmars (Fulmarus glacialis) from western Spitsbergen: the two species exhibited the dinoflagellate markers 22:6(n3) (6\%) and C18PUFAs (3\%) (Dahl et al. 2000; Dahl et al. 2003). This may indicate differences between the west Spitsbergen system, dominated by diatoms (Falk-Petersen et al. 2000), and the Franz Josef Land-Novaya Zemlya system, where this study indicates that dinoflagellates $-P$. phouchetii dominate.

The 20:1 and 22:1 moieties are formed de novo by Calanus spp. (Sargent \& Henderson 1986; Scott et al. 2002). The high levels of these two moieties in harp seal blubber $(15.1 \%$ and $7.6 \%$, respectively) show the importance of Calanus spp. in the harp seal food chain. Calanus spp. have also been proved to be important in the food chain of beluga whale, northern fulmar and black-legged kittiwake (Rissa tridactyla) in Svalbard, in minke whales from the North Atlantic and in humpback whales (Megaptera novaeangliae) from the Gulf of St. Lawrence (Borobia et al. 1995; Dahl et al. 2000; Dahl et al. 2003; Møller et al. 2003; Olsen \& Grahl-Nielsen 2003). In contrast, harbour seals in Prince William Sound, Alaska, and grey seals

Table 3. Relative amounts (as \% of total) of 26 common fatty acids found in harp seal blubber fat. The 20 seals are designated by their sampling number and age (in parentheses).

\begin{tabular}{|c|c|c|c|c|c|c|c|c|c|c|c|c|c|c|c|c|c|c|c|c|}
\hline $\begin{array}{l}\text { Fatty } \\
\text { acids }\end{array}$ & $\begin{array}{l}12 \\
(0)\end{array}$ & $\begin{array}{l}14 \\
(0)\end{array}$ & $\begin{array}{l}03 \\
(1)\end{array}$ & $\begin{array}{l}13 \\
(1)\end{array}$ & $\begin{array}{l}30 \\
(1)\end{array}$ & $\begin{array}{l}06 \\
(2)\end{array}$ & $\begin{array}{l}28 \\
(2)\end{array}$ & $\begin{array}{l}26 \\
(3)\end{array}$ & $\begin{array}{l}15 \\
(9)\end{array}$ & $\begin{array}{l}18 \\
(9)\end{array}$ & $\begin{array}{c}29 \\
(10)\end{array}$ & $\begin{array}{c}20 \\
(12)\end{array}$ & $\begin{array}{c}24 \\
(12)\end{array}$ & $\begin{array}{c}23 \\
(13)\end{array}$ & $\begin{array}{c}21 \\
(16)\end{array}$ & $\begin{array}{c}19 \\
(17)\end{array}$ & $\begin{array}{c}42 \\
(17)\end{array}$ & $\begin{array}{c}17 \\
(21)\end{array}$ & $\begin{array}{c}25 \\
(23)\end{array}$ & $\begin{array}{l}22 \\
(24)\end{array}$ \\
\hline $14: 0$ & 7.8 & 7.7 & 12.2 & 8.2 & 7.8 & 8.1 & 6.3 & 6.5 & 8.3 & 8.5 & 6.9 & 8.3 & 7.1 & 7.1 & 6.6 & 8.5 & 7.9 & 6.2 & 6.2 & 6.3 \\
\hline $15: 0$ & 0.3 & 0.4 & 0.7 & 0.4 & 0.3 & 0.4 & 0.3 & 0.3 & 0.3 & 0.3 & 0.3 & 0.3 & 0.3 & 0.3 & 0.3 & 0.4 & 0.3 & 0.4 & 0.3 & 0.3 \\
\hline 16:0 & 15.1 & 8.1 & 8.0 & 11.8 & 9.9 & 9.8 & 9.4 & 7.6 & 12.3 & 7.3 & 7.3 & 8.4 & 6.8 & 8.5 & 11.3 & 9.7 & 8.8 & 9.5 & 10.9 & 8.5 \\
\hline $16: 1(n-7)$ & 11.1 & 7.9 & 6.1 & 12.4 & 7.6 & 11.1 & 8.1 & 12.0 & 11.9 & 6.4 & 10.6 & 7.8 & 8.9 & 7.9 & 6.4 & 5.8 & 12.5 & 8.4 & 9.3 & 7.5 \\
\hline $16: 2$ & 0.8 & 0.8 & 0.4 & 0.7 & 0.7 & 0.7 & 0.8 & 0.9 & 0.7 & 0.6 & 0.8 & 0.7 & 0.7 & 0.6 & 0.7 & 0.6 & 0.8 & 0.7 & 0.7 & 0.7 \\
\hline $16: 3$ & 0.2 & 0.4 & 0.2 & 0.2 & 0.2 & 0.2 & 0.3 & 0.5 & 0.2 & 0.2 & 0.4 & 0.2 & 0.4 & 0.2 & 0.2 & 0.2 & 0.4 & 0.3 & 0.7 & 0.3 \\
\hline $16: 4$ & 0.4 & 0.4 & 0.3 & 0.3 & 0.3 & 0.4 & 0.5 & 0.8 & 0.4 & 0.3 & 0.8 & 0.4 & 0.5 & 0.3 & 0.4 & 0.4 & 0.5 & 0.4 & 0.2 & 0.5 \\
\hline $17: 0^{\mathrm{a}}$ & 0.4 & 0.7 & 1.0 & 0.5 & 0.6 & 0.5 & 0.5 & 0.4 & 0.4 & 0.8 & 0.5 & 0.7 & 5.5 & 0.6 & 0.6 & 0.7 & 0.4 & 0.6 & 0.5 & 0.6 \\
\hline $18: 0$ & 1.8 & 1.5 & 1.5 & 1.4 & 1.5 & 1.2 & 1.8 & 1.2 & 1.3 & 1.4 & 1.3 & 1.3 & 1.2 & 1.4 & 2.2 & 1.7 & 1.1 & 1.5 & 1.5 & 1.6 \\
\hline $18: 1(n-9)^{b}$ & 18.5 & 12.9 & 13.1 & 18.0 & 15.4 & 19.1 & 8.8 & 10.5 & 20.2 & 12.0 & 11.2 & 14.4 & 10.4 & 17.1 & 15.6 & 15.2 & 11.1 & 13.3 & 16.4 & 15.5 \\
\hline $18: 1(n-7)$ & 5.4 & 2.9 & 2.3 & 4.7 & 3.3 & 4.7 & 2.6 & 2.8 & 5.7 & 2.5 & 0.8 & 2.7 & 2.3 & 3.2 & 3.1 & 2.4 & 3.1 & 2.6 & 3.7 & 2.8 \\
\hline $18: 2(n-6)$ & 1.6 & 1.3 & 1.7 & 1.7 & 1.6 & 1.7 & 1.2 & 1.0 & 2.1 & 1.5 & 1.0 & 1.3 & 1.1 & 1.6 & 1.5 & 1.5 & 1.1 & 1.4 & 1.6 & 1.4 \\
\hline $18: 3(n-3)$ & 1.0 & 0.9 & 1.2 & 1.1 & 0.9 & 0.8 & 0.7 & 0.4 & 1.0 & 0.6 & 0.4 & 0.8 & 0.4 & 0.8 & 0.9 & 1.4 & 0.5 & 0.7 & 0.8 & 0.8 \\
\hline $18: 4(n-3)$ & 4.5 & 3.4 & 3.2 & 3.5 & 3.3 & 2.9 & 3.0 & 2.1 & 4.3 & 2.3 & 2.3 & 3.3 & 1.9 & 3.1 & 3.5 & 4.4 & 2.4 & 3.3 & 3.6 & 3.5 \\
\hline $20: 1(n-9)^{b}$ & 5.1 & 17.5 & 11.4 & 5.9 & 14.3 & 10.7 & 19.5 & 20.8 & 5.1 & 20.8 & 23.2 & 14.5 & 19.9 & 15.3 & 15.8 & 12.6 & 12.1 & 16.5 & 14.8 & 16.6 \\
\hline $20: 1(n-7)$ & 0.3 & 0.6 & 0.4 & 0.3 & 0.4 & 0.4 & 0.5 & 0.7 & 0.3 & 0.5 & 0.8 & 0.5 & 0.7 & 0.4 & 0.4 & 0.3 & 0.5 & 0.4 & 0.4 & 0.5 \\
\hline $20: 3(n-6)$ & 0.1 & 0.2 & 0.0 & 0.1 & 0.1 & 0.1 & 0.1 & 0.1 & 0.1 & 0.1 & 0.1 & 0.1 & 0.1 & 0.1 & 0.1 & 0.1 & 0.0 & 0.1 & 0.1 & 0.1 \\
\hline $20: 4(n-6)$ & 0.4 & 0.5 & 0.4 & 0.4 & 0.4 & 0.3 & 0.4 & 0.3 & 0.4 & 0.3 & 0.3 & 0.4 & 0.3 & 0.4 & 0.4 & 0.5 & 0.4 & 0.4 & 0.4 & 0.4 \\
\hline $20: 4(n-3)$ & 0.5 & 0.9 & 0.8 & 0.7 & 0.8 & 0.6 & 0.9 & 0.1 & 0.4 & 0.8 & 0.7 & 1.0 & 0.7 & 0.8 & 0.9 & 1.1 & 0.8 & 0.8 & 0.7 & 1.1 \\
\hline $20: 5(n-3)$ & 9.0 & 4.5 & 2.8 & 7.1 & 4.5 & 4.9 & 6.8 & 6.6 & 7.9 & 3.1 & 6.1 & 5.4 & 4.4 & 3.9 & 5.3 & 5.0 & 10.5 & 6.1 & 7.1 & 4.7 \\
\hline $21: 5$ & 0.6 & 0.7 & 0.7 & 0.5 & 0.6 & 0.6 & 0.7 & 0.6 & 1.0 & 0.6 & 0.6 & 0.6 & 0.6 & 0.6 & 0.6 & 0.7 & 0.5 & 0.6 & 0.6 & 0.7 \\
\hline $22: 1(n-11)$ & 1.8 & 8.0 & 6.7 & 3.3 & 7.5 & 3.6 & 9.5 & 8.9 & 1.5 & 9.9 & 8.4 & 7.0 & 9.5 & 7.6 & 6.8 & 6.6 & 4.0 & 8.9 & 4.1 & 6.6 \\
\hline $22: 1(n-9)$ & 0.3 & 1.1 & 0.9 & 0.3 & 1.0 & 0.7 & 1.4 & 1.4 & 0.3 & 1.4 & 1.6 & 1.1 & 1.7 & 1.1 & 0.9 & 0.7 & 0.7 & 1.1 & 0.7 & 1.0 \\
\hline $22: 5(n-3)$ & 4.0 & 3.7 & 3.9 & 3.8 & 3.5 & 3.9 & 3.5 & 3.8 & 3.5 & 4.1 & 3.2 & 3.8 & 3.6 & 4.2 & 3.1 & 4.4 & 4.4 & 3.4 & 3.2 & 4.6 \\
\hline $22: 6(n-3)$ & 6.6 & 9.5 & 13.3 & 9.6 & 9.8 & 8.1 & 9.7 & 8.2 & 7.0 & 9.5 & 7.4 & 10.7 & 7.5 & 10.1 & 10.2 & 12.5 & 11.4 & 9.7 & 9.3 & 11.0 \\
\hline $24: 1(n-9)$ & 0.1 & 0.3 & 0.5 & 0.3 & 0.4 & 0.2 & 0.3 & 0.2 & 0.1 & 0.5 & 0.2 & 0.4 & 0.4 & 0.4 & 0.3 & 0.4 & 0.0 & 0.3 & 0.1 & 0.2 \\
\hline$\sum 20: 1$ & 5.4 & 18.1 & 11.7 & 6.2 & 14.8 & 11.1 & 20.1 & 21.5 & 5.4 & 21.3 & 24.0 & 14.9 & 20.6 & 15.7 & 16.2 & 12.9 & 12.6 & 16.9 & 15.2 & 17.1 \\
\hline$\sum 22: 1$ & 2.1 & 9.1 & 7.6 & 3.6 & 8.5 & 4.3 & 10.9 & 10.3 & 1.8 & 11.3 & 9.9 & 8.0 & 11.3 & 8.7 & 7.7 & 7.3 & 4.6 & 10.1 & 4.8 & 7.6 \\
\hline $22: 1 / 20: 1$ & 0.4 & 0.5 & 0.6 & 0.6 & 0.6 & 0.4 & 0.5 & 0.5 & 0.3 & 0.5 & 0.4 & 0.5 & 0.5 & 0.6 & 0.5 & 0.6 & 0.4 & 0.6 & 0.3 & 0.4 \\
\hline $\begin{array}{l}20: 5(n-3) \\
/ 22: 6(n-3)\end{array}$ & 1.4 & 0.5 & 0.2 & 0.7 & 0.5 & 0.6 & 0.7 & 0.8 & 1.1 & 0.3 & 0.8 & 0.5 & 0.6 & 0.4 & 0.5 & 0.4 & 0.9 & 0.6 & 0.8 & 0.4 \\
\hline
\end{tabular}

a Both branched and unbranched. $\quad$ b Both $n-9$ and $n-11$ isomers. 
(Halichoreus grypus) from Scotland had low values of the 20:1 and 22:1 moieties (Iverson et al. 1997; Walton \& Pomeroy 2003). The high levels of dinoflagellate and Calanus FATMs in Franz Josef Land-Novaya Zemlya harp seals show that the lipids of harp seal food, such as polar cod and T. libellula, originate from dinoflagellates and Calanus copepods. The high level of Calanus FATMs in many high latitude birds and mammals indicates a key position of Calanus spp. at the base of their food chain.

Table 4. Mean relative amounts (as \% of total) of 29 moieties most commonly found in harp seals and potential prey organisms. $\mathrm{N}=$ number of replicates

\begin{tabular}{|c|c|c|c|c|c|c|}
\hline Moiety & 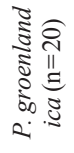 & 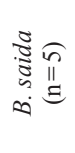 & 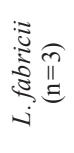 & 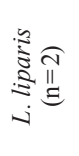 & 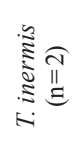 & 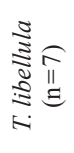 \\
\hline 14:0 & 7.6 & 2.7 & 1.8 & 4.0 & 8.9 & 5.0 \\
\hline 15:0 & 0.4 & 0.3 & 0.4 & 0.3 & 0.5 & 0.3 \\
\hline Branched 16:0 & 0.0 & 0.0 & 3.1 & 0.0 & 0.0 & 0.0 \\
\hline $16: 0$ & 9.5 & 8.2 & 18.2 & 17.9 & 29.8 & 10.0 \\
\hline $16: 1(n-7)$ & 9.0 & 11.9 & 8.2 & 14.6 & 16.5 & 13.6 \\
\hline iso $17: 0$ & 0.8 & 0.2 & 0.6 & 0.0 & 0.0 & 0.0 \\
\hline $16: 2$ & 0.7 & 0.6 & 0.3 & 0.3 & 1.0 & 0.6 \\
\hline $16: 3$ & 0.3 & 0.3 & 0.0 & 0.0 & 0.5 & 0.5 \\
\hline $16: 4$ & 0.4 & 0.2 & 0.0 & 0.2 & 0.4 & 0.7 \\
\hline iso $17: 1$ & 0.0 & 0.2 & 0.7 & 0.0 & 0.0 & 0.0 \\
\hline Phytanic acid & 0.0 & 0.0 & 0.0 & 1.4 & 0.0 & 0.0 \\
\hline $18: 0$ & 1.5 & 1.3 & 2.3 & 1.8 & 1.6 & 0.5 \\
\hline $18: 1(n-9)^{a}$ & 14.4 & 8.4 & 15.9 & 27.9 & 21.0 & 6.3 \\
\hline 18:1(n-7) & 3.2 & 2.9 & 11.9 & 14.6 & 9.2 & 2.6 \\
\hline $18: 2(n-6)$ & 1.4 & 0.8 & 1.2 & 0.9 & 0.7 & 0.8 \\
\hline $18: 3(n-3)$ & 0.8 & 0.3 & 0.4 & 0.2 & 0.4 & 0.5 \\
\hline $18: 4(n-3)$ & 3.2 & 2.6 & 1.0 & 0.1 & 2.5 & 2.7 \\
\hline $20: 1(n-9)^{a}$ & 14.6 & 18.6 & 1.9 & 6.1 & 1.0 & 20.8 \\
\hline $20: 1(n-7)$ & 0.5 & 1.1 & 2.4 & 0.7 & 0.2 & 0.8 \\
\hline $20: 2(n-6)$ & 0.3 & 0.1 & 0.4 & 0.5 & 0.2 & 0.1 \\
\hline $20: 4(n-6)$ & 0.4 & 0.4 & 1.9 & 0.7 & 0.1 & 0.2 \\
\hline $20: 4(n-3)$ & 0.8 & 0.5 & 0.3 & 0.2 & 0.1 & 0.4 \\
\hline $20: 5(n-3)$ & 5.8 & 9.5 & 11.5 & 2.8 & 2.9 & 12.0 \\
\hline $21: 5$ & 0.6 & 0.0 & 0.0 & 0.0 & 0.0 & 0.0 \\
\hline $22: 1(n-11)$ & 6.5 & 15.7 & 0.5 & 1.1 & 1.1 & 0.0 \\
\hline $22: 1(n-9)$ & 1.0 & 2.2 & 0.8 & 0.3 & 0.1 & 0.0 \\
\hline $22: 1 \mathrm{~s}$ & 7.6 & 18.3 & 1.5 & 1.4 & 1.2 & 13.0 \\
\hline $22: 5(n-3)$ & 3.8 & 1.0 & 0.9 & 0.0 & 0.0 & 0.5 \\
\hline $22: 6(n-3)$ & 9.6 & 7.4 & 7.7 & 0.8 & 0.5 & 5.9 \\
\hline$\sum 20: 1$ & 15.1 & 19.7 & 4.3 & 6.9 & 1.2 & 21.6 \\
\hline$\sum 22: 1$ & 7.6 & 18.3 & 1.5 & 1.4 & 1.2 & 13.0 \\
\hline $22: 1 / 20: 1$ & 0.5 & 0.9 & 0.3 & 0.2 & 1.0 & 0.8 \\
\hline $20: 5(n-3) / 22: 6(n-3)$ & 0.6 & 1.3 & 1.5 & 3.5 & 5.4 & 2.0 \\
\hline
\end{tabular}

\footnotetext{
${ }^{a}$ Both $\mathrm{n}-9$ and $\mathrm{n}-11$ isomers.
}

\section{References}

Arim, M. \& Naya, D. E. 2003: Pinniped diets inferred from scats: analyses of biases in prey occurrences. Can. J. Zoology 81, 67-73.

Barrett, R. T. 2002: Atlantic puffin Fratecula arctica and common guillemot Uria aalge chick and growth as indicators of fish stocks in the Barents Sea. Mar. Ecol. Progr. Ser. 230, 275-287.

Beck, G. G., Hammill, M. O. \& Smith, T. G. 1993: Seasonal variation in the diet of harp seals (Phoca groenlandica) from the Gulf of St. Lawrence and western Hudson Strait. Can. J. Fish. Aquat. Sci. 50, 1363-1371.

Best, N. J., Bradshaw, C. J. A., Hindell, M. A. \& Nichols, P. D. 2003: Vertical stratification of fatty acids in the blubber of southern elephant seals (Mirounga leonina): implications for diet analysis. Comp. Biochem. Physiol. Part B Biochem. Mol. Biol. 134, 253-263.

Birks, H. J. B. 1987: Multivariate analysis in geology and geochemistry-an introduction. Chemometrics Intelligent Lab. Syst. 2, 15-28.

Borobia, M., Gearing, P. J., Simard, Y., Gearing, J. N. \& Béland, P. 1995: Blubber fatty acids of finback and humpback whales from the Gulf of St. Lawrence. Mar. Biol. 122, 341-353.

Bowen, W. D. 2000: Reconstruction of pinniped diets: accounting for complete digestion of otoliths and cephalopod beaks. Can. J. Fish. Aquat. Sci. 57, 898-905.

Bowen, W. D., Sergeant, D. E. \& Oritsland, T. 1983: Validation of age estimation in the harp seal, Phoca groenlandica, using dentinal annuli. Can. J. Fish. Aquat. Sci. 40, 1430-1441.

Brown, D. J., Boyd, I. L., Cripps, G. C. \& Butler, P. J. 1999: Fatty acid signature analysis from the milk of Antarctic fur seals and southern elephant seals from South Georgia: implications for diet determination Mar. Ecol. Progr. Ser. 187, 251-263.

Cook, H. W. 1985: Fatty acid desaturation and chain elongation in eucaryotes. In D. E. Vance \& J. E. Vance (eds.): Biochemistry of lipids and membranes. Pp. 181-211. Menlo Park. CA: Benjamin/Cumming.

Dahl, T. M., Falk-Petersen, S., Sargent, J., Gabrielsen, G., Hop, H. \& Millar, R. M. 2003: Lipids and stable isotopes in common eider, black-legged kittiwake and northern fulmar - a trophic study from an Arctic fjord. Mar. Ecol. Progr. Ser. 256, 257-269.

Dahl, T. M., Lydersen, C., Kovacs K. M., Falk-Petersen, S., Sargent, J., Gjertz, I. \& Gulliksen, B. 2000: Fatty acid composition of the blubber in white whales (Delphinapterus leucas). Polar Biol. 23, 401-409.

Dalsgaard, J., St. John, M., Gerard, K., Müller-Navarra, D. \& Hagen, W. 2003: Fatty acid trophic markers in the pelagic marine environment. Adv. Mar. Biol. 46, 227-318.

Day, R. W. \& Quinn, G. P. 1989: Comparison of treatments after an analysis of variance in ecology. Ecol. Monogr. 59, 433-463.

Falk-Petersen, S., Dahl, T. M., Scott, C., Sargent, J., Gulliksen, B., Kwasniewski, S., Hop, H. \& Millar, R. 2002: Lipid biomarkers and trophic linkages between ctenophores and copepods in Svalbard waters. Mar. Ecol. Progr. Ser. 227, 187-194.

Falk-Petersen, S., Falk-Petersen I.-B. \& Sargent J. R. 1986: Structure and function of an unusual lipid storage organ in the Arctic fish Lumpenus maculatus (Fries). Sarsia 71, 1-6. 
Falk-Petersen, S., Hagen, W., Kattner, G., Clarke, A. \& Sargent, J. R. 2000: Lipids, trophic relationships and biodiversity in Arctic and Antarctic krill. Can. J. Fish. Aquat. Sci. 57, 178-191.

Falk-Petersen, S., Hopkins, C. C. E. \& Sargent, J. R. 1990: Trophic relationships in the pelagic food web. In M. Barnes \& R. N. Gibson (eds.): Trophic relationships in the marine environment. Pp. 315-333. Aberdeen: Aberdeen University Press.

Fea, N. \& Harcourt, R. 1997: Assessing the use of fecal and regurgitate analysis as means of determining the diet of New Zealand fur seals. In M. Hindell and C. Kemper (eds.): Marine mammal research in the Southern Hemisphere: status, ecology and medicine. Pp. 143-150. Chipping Norton: Surrey Beatty and Sons Ltd.

Folch, J. M., Lees, M. \& Sloane, G. H. 1957: A simple method for the isolation and purification of total lipid from animal tissues. J. Biol. Chem. 226, 497-509.

Folkow, L. P., Nordøy, E. S. \& Blix, A. S. 2004: Distribution and diving behaviour of harp seals (Pagophilus groenlandicus) from the Greenland Sea stock. Polar Biol. 27, 281-298.

Gjøsæter, H. 1998: The population biology and exploitation of capelin (Mallotus villosus) in the Barents Sea. Sarsia 83, 453-496.

Grahl-Nielsen, O. \& Mjaavatten, O. 1991: Dietary influence on fatty acid composition of blubber fat of seals as determined by biopsy: a multivariate approach. Mar. Biol. 110 59-64.

Hair, J. F., Anderson, R. E., Tathan, R. L. \& Black, W. C. (eds.) 1998: Multivariate data analysis. Upper Saddle River, NJ: Prentice Hall International.

Hammill, M. O. \& Stenson, G. B. 2000: Estimated prey consumption by harp seals (Phoca groenlandica), hooded seals (Cystophora cristata), grey seals (Halichoerus grypus) and harbour seals (Phoca vitulina) in Atlantic Canada. J. Northwest Atl. Fish. Sci. 26, 1-23.

Haug, T., Nilssen, K. T. \& Linblom, C. 2000: First independent feeding of harp seal (Phoca groenlandica) and hooded seal (Crystophora cristata) pups in the Greenland Sea. NAMMCO Sci. Publ. 2, 29-39.

Haug, T., Nilssen K. T., Øien, N. \& Potelov, V. 1994: Seasonal distribution of harp seals (Phoca groenlandica) in the Barents Sea. Polar Res. 13, 163-172.

Iverson, S. J. 1993: Milk secretion in marine mammals in relation to forging: can milk fatty acids predict diet? Symp. Zool. Soc. Lond. 66, 263-291.

Iverson, S. J. 1995: Principles of fatty acid signature analysis and its use in studying foraging ecology and diets of marine mammals. Paper presented at the ICES/NAFO symposium: Role of Marine Mammals in the Ecosystem. Dartmouth, Nova Scotia. 6-8 September.

Iverson, S. J., Frost, K. J. \& Lowry, L. F. 1997: Fatty acid signatures reveal fine scale structure of foraging distribution of harbour seals and their prey in Prince William Sound, Alaska. Mar. Ecol. Progr. Ser. 151, 255-271.

Kvalheim, O. M. \& Kvarstang, T. V. 1987: A general-purpose program for multivariate data analysis. Chemometrics Intelligent Lab. Syst. 2, 235-237.

Lawson, J. W. \& Stenson, G. B. 1997: Diet of northwest Atlantic harp seals (Phoca groenlandica) in offshore areas. Can J. Zoology 75, 2095-2106.

Lea, M. A., Cherel, Y., Guinet, C. \& Nichols, N. P. 2002: Antarctic fur seals foraging in the Polar Frontal Zone: interannual shifts in diet as shown from fecal and fatty acid analyses. Mar. Ecol. Progr. Ser. 245, 281-297.

Lindstrøm, U., Harbitz, A., Haug, T. \& Nilssen, K. T. 1998 Do harp seals Phoca groenlandica exhibit particular prey preferences? ICES J. Mar. Sci. 55, 941-953.

Nilssen, K. T., Grotnes, P. E., Haug, T. \& Potelov, V. 1997: Seasonal variation in body condition of adult Barents Sea harp seals (Phoca groenlandica). J. Northwest Atl. Fish. Sci. 22, 17-25.

Nilssen, K. T., Haug, T., Potelov, V., Stasenkov, V. A. \& Timoshenko, Y. K. 1995: Food habits of harp seals (Phoca groenlandica) during lactation and moult in March-May in the southern Barents Sea and White Sea. ICES J. Mar. Sci. 52, 33-41.

Nilssen, K. T., Haug, T., Potelov, V., Timoshenko, Y. K. 1995: Feeding habits of harp seals (Phoca groenlandica) during early summer and autumn in the northern Barents Sea. Polar Biol. 15, 485-493.

Nilssen, K. T., Pedersen, O. P., Folkow, L. P. \& Haug, T. 2000 Food consumption estimates of Barents Sea harp seals. NAMMCO Sci. Publ. 2, 9-27.

Olsen, E. \& Grahl-Nielsen, O. 2003: Blubber fatty acids of minke whales: stratification, population identification and relation to diet. Mar. Biol. 142, 13-24.

Olsen, O. J. \& Henderson, R. J. 1989: The rapid analysis of neutral and polar lipids using double-development HPTLC and scanning densiometry. J. Exp. Mar. Biol. Ecol. 129, 189-197.

Pierce, G. J. \& Boyle, P. R. 1991: A review of methods for diet analysis in piscivorous marine mammals. In M. Barns (ed.): Oceanography and marine biology annual review 29. Pp. 409-486. Aberdeen: Aberdeen University Press.

Ryg, M., Smith, T. G. \& Oritsland, N. A. 1990: Seasonal changes in body mass and body composition of ringed seals (Phoca hispida) on Svalbard. Can. J. Zool. 68, 470-475.

Sargent, J. R. \& Falk-Petersen, S. 1981: Ecological investigation on the zooplankton community of Balsfjorden, northern Norway: lipids and fatty acids in Thysanoessa inermis (Krøyer), Thysanoessa raschii (M. Sars) and Meganytiphanes norvegica (M. Sars) during mid-winter. Mar. Biol. 62, 131-137.

Sargent, J. R. \& Henderson, R. J. 1986: Lipids. In E. D. S. Corner \& S. C. M. O'Hara (eds.): The biological chemistry of marine copepods. Pp. 59-164. Oxford: Clarendon Press.

Sergeant, D. E. 1991: Harp seals, man and ice. Can. Spec. Publ. Fish. Aquat. Sci. 114. Ottawa: Department of Fisheries and Oceans.

Sivertsen, E. 1941: On the biology of the harp seal Phoca groenlandica Erxl. Investigations carried out in the White Sea 1925-1937. Hvalrådets Skrifter 26.

Sokahl, R. R. \& Rohlf, F. J. 1995: Biometry. Third edition. New York: WH Freeman and Company.

Tierney, M., Hindell, M., Lea, M. A. \& Tollit, D. 2001: A comparison of techniques used to estimate body condition of southern elephant seals (Mirounga leonina). Wildl. Res. 28, 581-588.

Walton, M. \& Pomeroy, P. 2003: Use of blubber fatty acid profiles to detect inter-annual variations in the diet of grey seals Halichoerus grypus. Mar. Ecol. Progr. Ser. 248, 257266.

Wathne, J. A., Haug, T. \& Lydersen, C. 2000: Prey preference and niche overlap of ringed seals Phoca hispida and harp seals $P$. groenlandica in the Barents Sea. Mar. Ecol. Progr. Ser. 194, 233-239.

Wold, S. 1987: Principal component analysis. Chemometrics Intelligent Lab. Syst. 2, 37-52.

Lipids and trophic linkages in harp seal 